Portable camerae obscurae.

Figure 21 in Johann Zahn,

Oculus artificialis teledioptricus

sive Telescopicum (Würzburg,

1685).
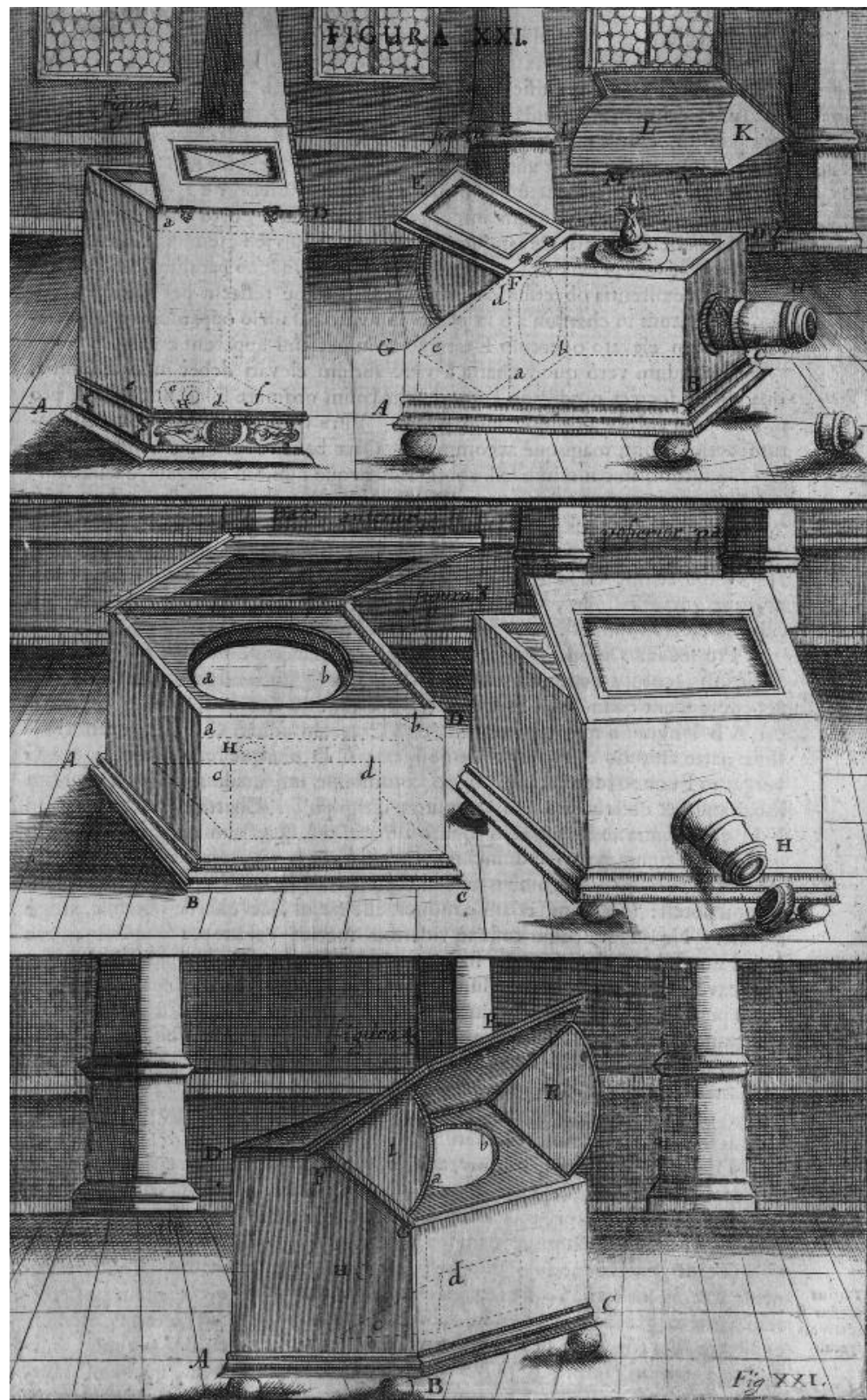


\section{Shadows of Expectation: Robert Hooke's Picture Box and the Visual Economy of Projection}

\section{PASI VÄLIAHO}

On December 19, 1694, eminent British natural philosopher Robert Hooke presented a paper to the Royal Society of London on "An Instrument of Use to Take the Draught, or Picture of Any Thing." ${ }^{1}$ Famous for his work on optical instruments and the study of light, among many other things, the fifty-nine-year-old "England's Leonardo" had, basically, just tweaked an ancient invention. What he presented to his fellows-a congregation of physicians, clergymen, noblemen, academics, and men of affairs-was a portable camera obscura. Hooke himself was quick to acknowledge that his invention was not exactly a "Thing that [had] never been done before." Camerae obscurae were originally literally dark chambers, equipped with a small aperture at one wall through which inverted light images were projected on the opposite wall. These chambers had been used in the study of light and shadow at least since the experiments conducted by the Arab mathematician Abu Ali al-Hasan Ibn al-Haytham circa $1000 \mathrm{CE}$, with a smallish box about 1.30 meters tall. ${ }^{2}$ By the seventeenth century in Europe, camerae obscurae had become key instruments in all sorts of scientific inquiries, in addition to aiding artists in tracing the outlines of objects and rendering shadows and tonal values. ${ }^{3}$ Significant developments to the design of these devices had also been made. Around 1670 in England, Robert Boyle, for whom Hooke worked as an assistant during the period, described his "portable darkened roome," a box camera equipped with an adjustable lens that afforded sharp projections of "Motions . . . Shapes and Colours of outward Objects" onto a sheet of paper. ${ }^{4}$ Across the Channel, the German Canon of the Premonstrate Order Johann Zahn provided the readers of his 1685 book Oculus artificialis with a variety of technical illustrations of portable camerae obscurae.

These designs, however, were not exactly what Hooke, curator of experiments at the Royal Society, had in mind. Instead of serving as an aid for making fine arts or as an instrument of scientific scrutiny strictly speaking, 
Hooke's invention was to gain advantage among "curious Navigators and Travelers," whom it would help to represent

true Forms and Shapes ... not only of the Prospects of Countries, and Coasts, as they appear at Sea from several Distances, and several Positions; but of divers In-land Prospects of Countries, Hills, Towns, Houses, Castles, and the like; as also of any Kind of Trees, Plants, Animals, whether Birds, Beasts, Fishes, Insects; nay, of Men, Habits, Fashions, Behaviours; as also, of all Variety of Artificial Things, as, Utensils, Instruments, Engines, Ships, Boats, Carriages, Weapons of War, and any Other Thing of which accurate Representation, and Explanation, is desirable. ${ }^{5}$

The "picture box," as Hooke called it, would allow potentially anything to be recorded by lay artists in an appropriate manner. Hooke described how the box was meant for "tracing profiles," for "running over the outlines" of things with one's pen-indeed, for making drafts. These sketches would be open for future modifications and could later be complemented with "proper Shadows and Light." ${ }^{\circ}$ Above all, the device was to facilitate the visual abstraction of the world; it would translate complex forms-landscapes of distant locations, coastlines, any visible appearance on the earth-into series of lines and zones. Unlike the whimsical drawings and stories of sailors, merchants, and other travelers of their excursions, which generally raised hills to "extravagant Heights,"7 Hooke contended, the picture box would allow visual information to be produced according to proper proportions and perspectives. It would allow the practice of what Svetlana Alpers calls "the art of describing," an art that is focused on attentive observation, relying heavily on optical technologies (from microscopes and telescopes to the dark room) to arrive at epistemic certainty about appearances, and that blurs "distinctions between measuring, recording, and picturing." 8

We do not know whether the design for a camera obscura that Hooke introduced to his fellows was ever built and used-quite likely not. Yet it is the imaginary of the apparatus that counts here more than its realization, an imaginary that can be witnessed in the anonymous woodcut of the picture box that was published after Hooke's death by William Derham, editor of a collection of Hooke's papers. The illustration's origins remain

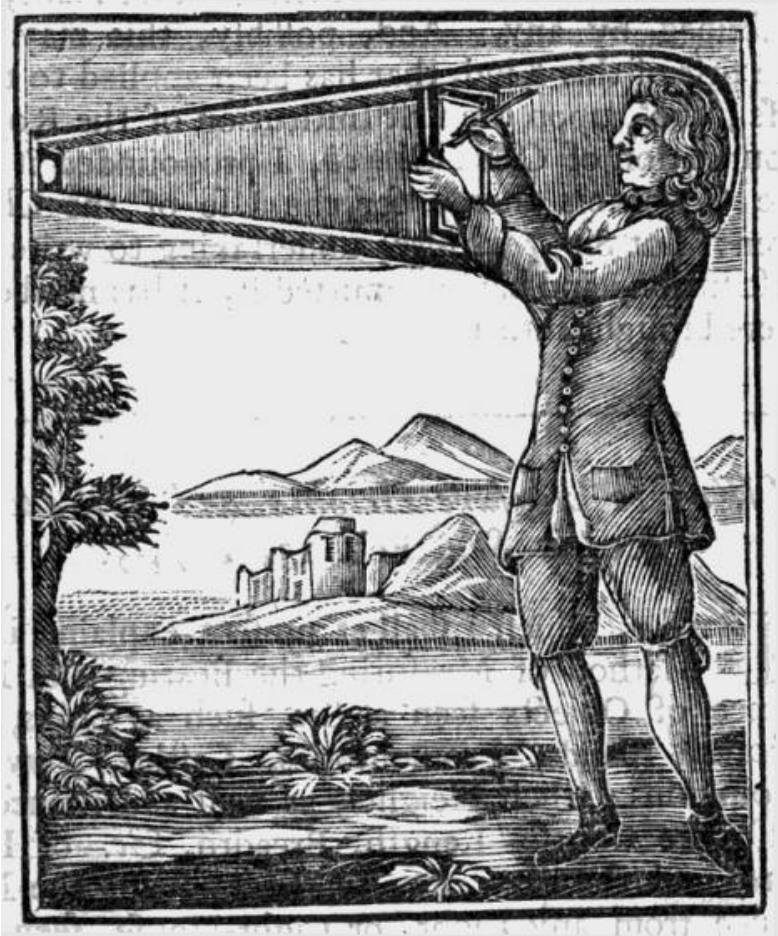


unknown, and they quite likely have little to do with Hooke himself. ${ }^{9}$ The engraving presents Hooke's model of a camera obscura as a curious kind of ergonomic design, not merely as portable but, above all, as a "wearable" wooden box that could be positioned over the observer's head and shoulders to facilitate drawing the sights projected inside the device. This "headmounted display," if one allows an anachronistic characterization, appears to rotate and move with the observer like a seminatural, although doubtless uncomfortable and awkward, extension of her or his body, or like "an artificial, dead eye," to borrow the words of Hooke's contemporary, the Jesuit astronomer Christoph Scheiner. ${ }^{10} \mathrm{~A}$ draftsman encased in the picture box surveys a seaside landscape with hilly islands and a castle, tracing something with his pen onto a paper support. The exotic flora suggests a distant location, a faraway place likely to be observed by "curious navigators and travelers" on their excursions.

For Hooke, the imperative was that, by drawing the outlines of things and beings, instead of relying merely on verbal expression, one could attain "the true Form of the Thing describ'd."11 The relevance of the picture box, for him, was embedded in the production and gathering of knowledge of things distant and foreign and perhaps even unheard of. But, as such, the objectives and uses of the box extended beyond what was professed, overlapping with the colonial conquests and economic developments within the Kingdom of England at the turn of the seventeenth and eighteenth centuries. Both the observer and the machine were, symptomatically in this respect, designed to be mobile, suggesting not only distant contemplation but the physical appropriation of territories. The gestures of screening, zooming, and drawing —and the very concept of optical projection-were here operationalized as part of the First Empire's networks of possession, travel, and trade.

\section{"Truth Will Be Pleas'd"}

In 1668, Hooke wrote about an "optical Experiment" he had arranged with a room-size camera obscura. Various "Apparitions and Disappearances" and "very delightful" effects, he envisioned, could be presented to credulous spectators, those not well versed in the secrets of optics, to incite their "passions of Love, Fear, Reverence, Honour, and Astonishment." 12 What Hooke contrived was an arrangement of visual spectacles in which actors and objects were placed outside the apparatus and simultaneously outside the viewer's awareness. Things both real and imaginary could thus be animated in an unprecedentedly vivid manner: "Apparitions of Angels, or Devils; Inscriptions and Oracles on Walls; the Prospect of Contryes, Cities, Houses, Navies, Armies; the Actions and Motions of Men, Beasts, Birds, \&c.” ${ }^{3}$ 
The dark chamber was to become a stage for artificial realities. ${ }^{14}$

Little of Hooke's 1668 experiments on optical trickery remains in his design of the portable dark room from about twenty-five years later. The latter model should be placed within a somewhat different intellectual as well as economic trajectory than the long history of magic spectacles and visual entertainment. Specific to Hooke's 1694 model of the camera obscura is how it grew out of the concerns of collecting and classifying distant "matters of fact" related to the Royal Society's epistemic conquest of foreign and hitherto unexplored parts of the world. Not only people closely associated with the society but ordinary travelers, seamen, and merchants, too, were harnessed to procure reports of their journeys worldwide. ${ }^{15}$ These included objects and artifacts alongside verbal accounts-specimens, raw materials, and all sorts of curiosities that arrived for the naturalists' perusal in the cargo of ships returning from overseas-as well as, in some cases, drawings, even if the travelers' picture-making skills were particularly questionable. ${ }^{16}$

In the Royal Society's accumulation of knowledge of natural history, things, pictures, and words came together in an epistemologically vital accord. ${ }^{17}$ All "data" about the parts of the world that remained to be fully explored and scrutinized were to be collected and preserved so as to come up with "as full and compleat a Collection of all varieties of Natural Bodies as could be obtain'd," as Hooke wrote (in relation to the Royal Society's repository of specimens, of which he was appointed the keeper in 1663). ${ }^{18}$ The key aim of the society was thereby to establish an "epistemic empire" alongside the political and economic one, an empire founded upon the empirical method of extracting knowledge from nature, based on observation, inductive reasoning, and experimentation with nature by means of technology. ${ }^{19}$ Here the savants of the Royal Society, among them Hooke, followed their intellectual father Francis Bacon's dictum to "enlarge the bounds of humane empire to the effecting of all things possible." ${ }^{20}$ As one of the society's founders, Henry Oldenburg proclaimed in 1667, "For we seek thoroughly to scrutinize everything - the heavens, the Earth, the subterranean world; the air, the meteors, and stars; rivers, seas, vegetables, minerals, animals; so that there is nothing of all this that you may not explore, wherever you turn." 21

The Royal Society was operating in a world of expanding and changing horizons. The Kingdom of England had been growing as a maritime power during the seventeenth century, and a motley of trading companies had started to establish themselves as global forces-even if the First Empire's reach over the globe was at this point a question of interlinked islands and coastal settlements rather than of centrally governed occupation of vast areas of territory. ${ }^{22}$ Fellows of the society were deeply entangled in the 
fledgling empire's various economic pursuits. Boyle, one of the society's founding members, for instance, owned shares in the Hudson's Bay Company and served on the board of the English East India Company. ${ }^{23}$ The latter was a leading financial-military complex of its times, realizing extensive profits and growth with its trade in cotton, silk, and tea, and had been granted semisovereign privileges to autonomously acquire and rule territories with its private army. ${ }^{24}$ Yet, upon Boyle's own account, the "desire of knowledge, not profit” drew him onto the East India Company's board alongside, as Boyle expounded elsewhere, the want to propagate "the gospel among the natives." ${ }^{25}$ Boyle crystallized how the authority of scripture, generally speaking, provided a moral foundation for the Royal Society's epistemic (and the Kingdom of England's financial and military) pursuits. For Boyle, natural philosophy obeyed as its final cause, and was thus legitimated by, God's original directions to Adam to establish an empire over the earth and its creatures:

It is recorded in the Book of Genesis, the design of God in making man was, that men should subdue the earth (as vast a globe as it is) and have dominion over the fish of the sea, and of the fowl of the air, and over the cattle, and over all the earth, and (to speak summarily) over every living thing that moveth upon the earth. ${ }^{26}$

The role of travel reporting for those pursuing Adam's task of planetary rule-the imperative to "have dominion . . . over all the earth, and over every creeping thing that creepeth upon the earth"-was critical. ${ }^{27}$ According to Hooke, descriptions of "parts and Regions of the Earth, whether Inhabited and Cultivated, or not Habitable or unfrequented" were "highly necessary to the augmenting and perfecting of Naturall philosophy." ${ }^{28}$ Yet how travelers' accounts connected observation, description, and matters of fact remained a significant epistemic concern. Pivotal to the fellows of the Royal Society was the matter of where their "informants" were to travel and what was to be observed and the proper direction and framing of the inquiries made. ${ }^{29}$ Boyle urged travelers to note details of longitude and latitude, temperature, tides, currents, the formation of plains, valleys, hills, and mountains. The particularities of flora and fauna as well as natural resources such as minerals, metals, and stones were important. Furthermore, Boyle noted, "there must be a careful account given of the Inhabitants themselves, both Natives and Strangers, that have been long settled there: And in particular their Stature, Shape, Colour, Features, Strength, Agility, Beauty (or the want of it) Complexions, Hair, Dyet, Inclinations, and Customs that seem not due to Education." 30

Boyle anticipated what Hooke pointed out in his preface to seaman 
Robert Knox's An Historical Relation of the Island of Ceylon from 1681 (a book that was financed by subscribers from the East India Company and produced in cooperation with the Royal Society scholars, Hooke in particular): the problem of regulating what was perceived as facts, as well as how these facts were gathered. ${ }^{31}$ "Truth will be pleas'd," Hooke praised Knox's memoirs, which were written after the seaman was released from his nineteen-year captivity on the island, but more often than not the flights of the informants' imagination had the tendency and power to overshadow actual states of affairs. Seamen and travelers, Hooke contended, needed instructions about "what is pertinent and considerable, to be observ' $\mathrm{d}$ in their Voyages and Abodes, and how make their Observations and keep Registers or Accounts of them." ${ }^{33}$ Above all, at issue was the truthfulness and integrity of the observers' accounts; that the accounts were "worthy of Credit," as the secretary of the East India Company suggested in his foreword to Knox's book.

In the 1694 note on the picture box, Hooke elaborated on these concerns:

I lately saw a Book containing the Prospects of all the Western Coasts of America; but any one, that understands Prospects, will easily discern, how rude, imperfect, and false a Representation, all such Books contain of the Places themselves: For, not to mention the Impossibilities they often represent, as the Over-hanging of Mountains for half a Mile, or a Mile, which, tho' the Mountain were made of cast Iron, were impossible to be sustain'd in such a Posture. ${ }^{33}$

Surely, as Hooke affirmed, imperfections in visualizations were often due to unskilled hands with little training in the "Art of Delineation" (unlike

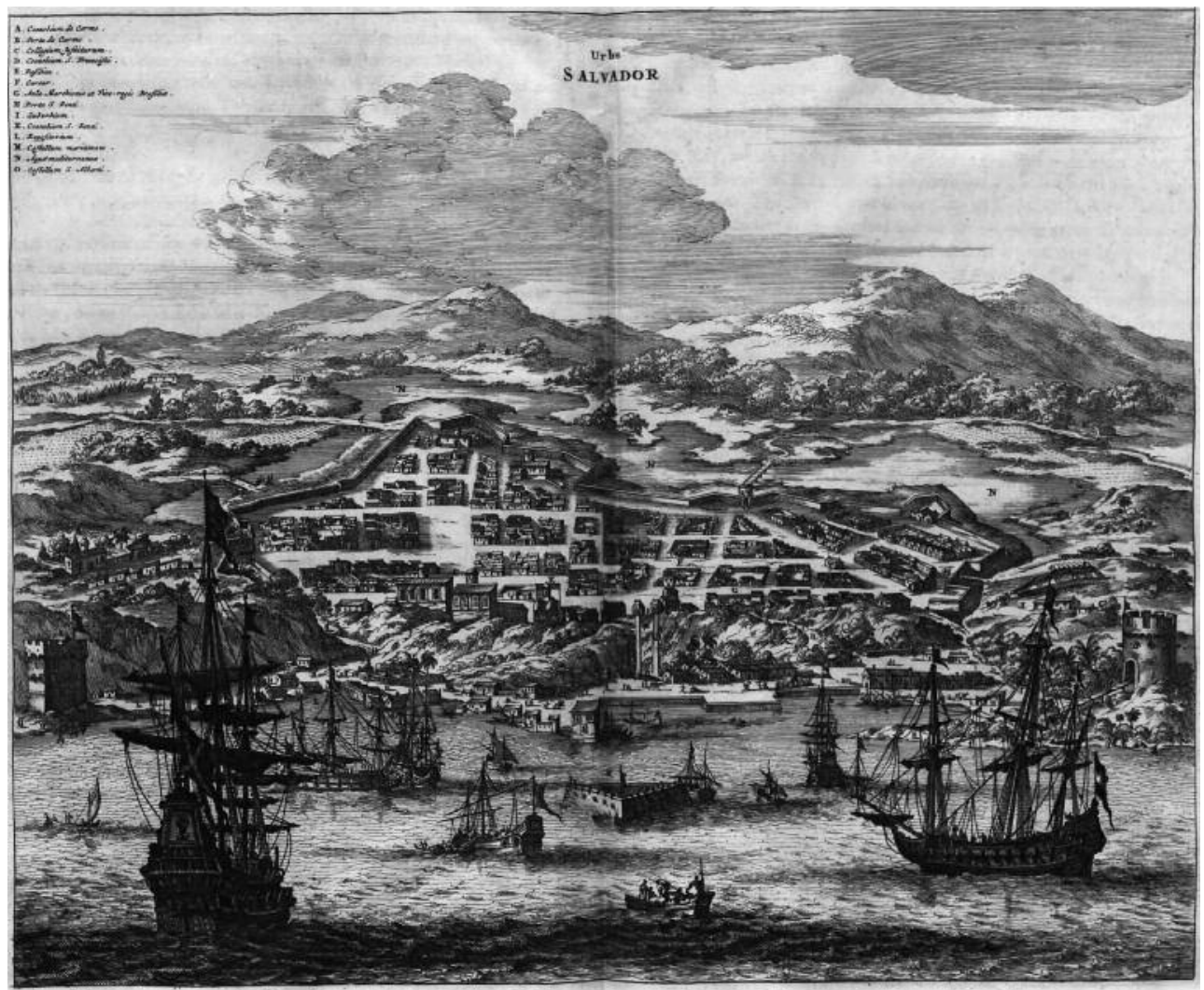


Hooke himself, who was well versed in draftsmanship). ${ }^{34}$ Illustrations published in travel books were even sometimes made by draftsmen in England based merely on verbal accounts or previous imagery-such as those produced for Knox's Relation, which seem to have been composed from a variety of sources, or the ones published in John Ogilby's America from 1671, which were reproduced from the Dutch original (and to which Hooke is probably referring in the above quotation). ${ }^{35}$ Such processes of mediation rather than eyewitness were anything but acceptable, Hooke objected, because the pictures could "misguide our Imagination, and lead us into Error, by obtruding upon us the Imaginations of a Person, possibly, more ignorant than ourselves."36

On September 22, 1683, a few months before Robert Knox was to sail off to Madagascar to take a cargo of slaves to St. Helena in the service of the East India Company, Hooke noted in his diary that he was "to present Cap" Knox . . . a picture box, an azimuth perspective [and] a longitude clock." 37 The latter two were instruments of surveying and navigation, while the "picture box" in question was quite probably a version of portable camera obscura designed to be used as a drawing aid-something Hooke had developed and presented to the Royal Society in the early summer of 1670 , adjusting the device's design to his fellow's suggestions over the course of a few trials. ${ }^{38}$ The final model of the "darkened box," we read in the minutes, was deemed "proper for the hand to draw a picture conveniently by a metalline speculum and a moveable bottom, whereby the picture appeared both erect and direct." ${ }^{39}$ At the turn of 1683-1684, a box assumedly of this kind was to join devices of mapping and delineation on a long journey overseas for the accumulation of both information and capital. The message from Hooke to Knox seems to have been that visualization was to be taken seriously as a measuring exercise during Knox's adventures and that its epistemic value was guaranteed by optical projections capable of restraining the mishaps and flights of "Mr. Engraver's fancy" (as Hooke wrote in relation to

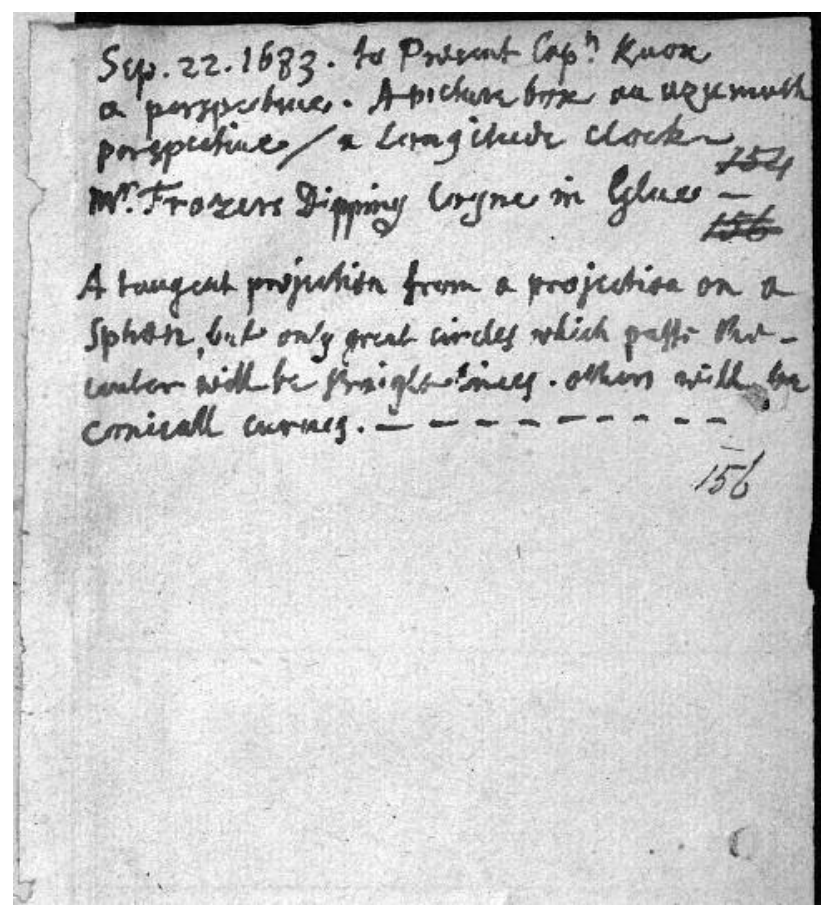

his 1694 model of the picture box). ${ }^{40}$

For Hooke, the camera obscura functioned as a mechanical eye that, like the physiological one, received "Representations of the outward Objects very perfect" but, unlike the human eye, was not misguided by the mind's whims. ${ }^{41}$ The box was above all to diminish the imagination's potential for distortion by disciplining the acts of both looking and drawing. Hooke's

Opposite: Illustration of the city of Salvador. From John Ogilby, America, Being the Latest and Most Accurate Description of the New World (London, 1671).

Left: Robert Hooke. Diary note, 22 September 1683. British Library, MS Sloane 1039, f. 156. By permission of the British Library. 
1694 design for a portable dark room should, in this sense, as Matthew Hunter suggests, be considered in relation to the devices of "machineassisted drawing" that the Royal Society fellows were innovating-devices that, by programming lines of sight and mechanizing the user's hand movements, helped schematize the world into grids and outlines. ${ }^{42}$ "Operative and Mechanick Knowledge” was achieved only by "a sincere Hand and a faithful Eye," Hooke wrote in the preface to Micrographia (1665)—something that the machine was to facilitate, offering "remedy" for the "dangers in the process of humane Reason." ${ }^{43}$ The picture box, whether portable or wearable, was purposed to regulate and standardize knowledge production by controlling what and how one is able to see, imagine, and draw. ${ }^{44}$

\section{"Worthy of Credit"}

The point of departure for such systematization of seeing and knowing was a reality projected on a screen instead of the reality that opens to so-called natural perception. The screen itself was nothing complicated: simply a translucent surface on which the observer witnessed the world becoming its own image (an inverted one if not corrected by a proper lens mechanism). As in any dark chamber, these images were born of light and shadow going through lenses, bouncing off mirrors (if any), and shrinking or expanding on conical paths. The camera obscura's projections were dynamic and "live" instead of being static, made of "Motions, Changes, and Actions.”45 A dark environment was necessary for these moving pictures to become visible. What the apparatus required was a separation between the system and the environment in terms of light (outside) and dark (inside). Thereby the projective screen came to impose itself between the observer and the environment. The screen, or tabula, as it was called in the seventeenth century, turned the world into a flat, two-dimensional plane. ${ }^{46}$ It rendered the environment as projected images that embodied the outside as a virtual reality inside the machine- “virtual" because the images were deprived of physical existence but possessed full color, form, and motion in appearance. The screen facilitated the production of hybrid images that blended semiautomatic projections with drawings and paintings made by human hand. ${ }^{47}$

The screen of Hooke's picture box, as Sean Silver describes it, was "the critical thing, serving, like a slash, as the figure for separating then linking subject and object, thinker and thought." ${ }^{48}$ The screen provided an auxiliary perceptual and cognitive mechanism by means of which the world could be outlined and surveyed-a mechanism akin to a grid that discloses things and beings by abstracting, systematizing, and operationalizing them according to a coordinate framework. In Hooke's time several other tabulae carried 
out similar operational and epistemic roles; most crucially, cartographic pictures. The Renaissance resuscitation of the cartographic projections developed by Claudius Ptolemy was imperative to Europe's colonization of the globe. The expansion of empires overseas relied on the projection of the earth's spherical volume onto a flat surface and the introduction of a geometrical grid of meridians and parallels. Now, the surface of the earth could be graphically coded-gridded, structured, and schematized-under a disembodied gaze that combined human, earthly agency with a panoptic overlook. Gone were the days of medieval mappae mundi, which represented a symbolic universe based on mythical and biblical narratives. What emerged instead were "planetary projections," even if unfinished and incomplete, that sought to conquer the unknown and the undiscovered in this world rather than reaching toward a heavenly beyond. ${ }^{49}$ Mapmaking hence fulfilled an imaginary of expansion whereby the earth could be spread out, within the projected image, like a surface to be occupied. With their grids and schemas, modern maps rendered territories as "suitable for administrative operations, for control, for management, for fiscal and economic planning." 50 They would serve not only as aids for navigation but as graphic inventories of, say, flora and fauna or native inhabitants, in addition to marking the boundaries of property. ${ }^{51}$

Should the projective screen of Hooke's picture box be considered in similar terms, as affording, like cartographic projections, possession through visualization? Did "projective" here mean "possessive" in the first instance? Hooke envisioned his device facilitating the production of recordings and measurements by means of perspective projection; perhaps he even had in mind the surveying and plotting of distances, heights, and shapes from pictures, thus conceptually linking optical with cartographic projectionsomething Hooke had already implied in a short diary entry from 1683 in which he put the picture box in relation to measuring devices, mapmaking, and navigation techniques. ${ }^{52}$ Furthermore, the anonymous engraver's interpretation of Hooke's design gestures toward something of the kind. The box appears to be intended, like maps, to mobilize the gaze and to incite action-and, simultaneously, to let its observer lay claim to the landscape through framing, looking, and drawing. ${ }^{53}$

Even if merely a footnote in history, buried in an old publication of Hooke's "philosophical experiments," the portable camera obscura did, thus understood, play a symbolic role in the Kingdom of England's program of economic expansion. If not any real deeds, it operationalized an imaginary-an imaginary of colonial conquest, to be sure, but more specifically an imaginary that linked optical projection with the pursuit of profit. The secretary of the East India Company expected words and pictures to be 
"worthy of Credit"-worthy, that is, not merely of trust but, first and foremost, of investment. The secretary's phrase divulges something crucial: natural philosophy, which screens and outlines matters of fact, was to provide the required background knowledge for scouting out new prospects for colonial settlement and trade, and thereby speculation on yields to come. Corporate commerce needed practical knowledge for its expansion, for setting up new bases, prospecting for natural resources, transplanting crops and people, and so on. ${ }^{54}$

The English saw the colonies as profit-returning property. "The Plantations are the Property of English Men,” the English commissioners negotiating for a union with Scotland asserted in the early years of the eighteenth century, "and that this Trade is of so great a consequence \& so beneficial as not to be communicated, as is Proposed, till all other Particulars which shall be thought necessary in this union be adjusted." 55 As this "so beneficial" trade advanced and expanded, the borders between knowledge and possession effectively blurred. For some of the Royal Society's fellows, like John Locke, the concerns of natural philosophy were mostly economic and governmental. From "rational and regular experiments," Locke argued, "we may draw advantages of ease and health, and thereby increase our stock of conveniences for this life." ${ }^{56}$ Knowledge, for Locke, should help one accumulate possessions and, furthermore, restore (as stipulated by the Old Testament) humankind's original dominion over the globe, making the earth fruitful and lucrative. ${ }^{57}$ Empirical investigations were thus needed for new invasions and for securing investments. This somewhat utilitarian conception of knowledge was complemented with Locke's theory of property, which the philosopher formulated while involved with the proprietors of the Carolina Company and while managing the colonial affairs of his patron, Lord Anthony Ashley Cooper. ${ }^{58}$ "As much land as a man tills, plants, improves, cultivates, and can use the product of," Locke wrote, "so much is his property. He by his labour does, as it were, enclose it from the common." 59 Through labor, property is established, boundaries and rights of ownership drawn, and the earth's fruits reaped. Wealth and possession thus boil down to "the labour of [man's] body, and the work of his hands" that are "properly his." 60

So Locke theorized his idea of "possessive individualism,” which tallied with the British colonial project of occupying, cultivating, and privatizing foreign territories-the Americas, the Caribbean, parts of Africa, and so on-that were to be "enclosed" and "improved" into sources of profit. ${ }^{61}$ Locke's musings also disclose something critical about Hooke’s picture box. The dark room, as Hooke pronounced, was intended to allow travelers to "take the draft or picture of any thing." ${ }^{2}$ The apparatus's hybrid images 
were thus more than mere depictions of foreign things and beings; they were intended to operate as acts of enclosure, justified and gratified by God's original command to "replenish the earth and subdue it," that would designate and outline the things and beings-fruits, trees, birds, hills, rivers, natives, and so on-meant to fall under one's ownership and care. ${ }^{63}$

Seeing and picture making, however, are not the same as actual deeds of conquering and approximating. "To find is not to see a thing with the eyes but to lay hold of it with the hands," the Dutch lawyer Hugo Grotius observed in his foundational treatise on international law, The Free Sea, from 1609. ${ }^{64}$ However, being able to lay one's hands on something presupposes a system of visualization and knowledge production that secures the sphere of objects to be acted upon in the first place. Martin Heidegger notes that modern science (and the development of modern empires) relies on projection (Entwurf) as one of its key cognitive operations allowing the taming of the unknown by turning it into a picture-a projection, in the sense of casting an image but also of sketching, outlining, and scheming, as the German Entwurf suggests. ${ }^{65}$ "Projection," Heidegger writes, "sketches out in advance the manner in which the knowing procedure must bind itself and adhere to the sphere opened up." ${ }^{6}$ In Hooke's picture box, to follow this line of thought, projection was a way of sketching in advance things and beings as "worthy of Credit"—of delineating and evaluating something as a possible object of investment and improvement. Projection thus comes across as a key operation in the anticipation of economic gain, as a critical disposition whereby discovery and expansion-that is, laying hold of something with one's hands-however abstractly, could take place.

\section{"Shadows of Expectation"}

What can be said about the anonymous person in the anonymous engraving of Hooke's picture box-the one who, immersed in the device, marches over foreign land, visualizes, and eventually appropriates the unknown; the one who, while enclosing the earth from the common, becomes himself enclosed into the apparatus's animated visions, which darken shadows, strengthen contrast, and deepen colors? ${ }^{67}$ Who was this person? A new type of capitalist, one could argue, for whom the accumulation of wealth was based on projecting in the sense of scheming and speculating-the worth of things and beings being derived from what they will sell for, from their probable future value. As a jingle in Malachy Postlethwayt's The Universal Dictionary of Trade and Commerce (1774) teaches,

For what's the worth of any thing?

But just as much as it will bring. ${ }^{6}$ 
We might give the anonymous draftsman "the despicable title of a projector," to borrow the words of Daniel Defoe from his first published work, "An Essay upon Projects" (1697). ${ }^{69}$ The word projector was in Hooke's and Defoe's times used to denote, as a dictionary from 1756 tells us, someone "who forms schemes and designs," even "wild impracticable schemes."70 "To project" was understood as "to throw out" or "to exhibit a form" (as in projecting an image) but also as "to scheme, to form in the mind, to contrive." 71 Projecting connoted the production of images, internal or external, that plot, in one way or another, the future in view of making profit. Projecting meant turning the world into its speculative, virtual image.

Defoe even labels his times as a "Projecting Age," an age that "swarms with . . . a multitude of projectors more than usual."72 By this he indicates the expansion of innovations in engineering and science sparked by the hostilities between England and France in the Nine Years' War-hostilities that were caused by rivalry over, among other things, control of networks of maritime trade and colonial markets. But the waging of war also precipitated what historians refer to as the "financial revolution," which started in England in the late-seventeenth century with such economic developments as the establishment of a banking structure, the creation of a system of public credit whereby individuals and companies could invest money in the government, and the development of joint-stock companies and insurance services. ${ }^{73}$ Defoe refers to these innovations in finance economy with particular scorn, as forms of "projection." He observes of merchants involved in overseas trade, who weighed yields against risks, that "to these sort of men it is easy to trace the original of banks, stocks, stock-jobbing, assurances, friendly societies, lotteries, and the like." ${ }^{74}$ Those joining in market activity -in the transmission of credit and debt, stock exchange, and so on-came across largely as self-interested, corrupt individuals endowed with a special "faculty of projecting." This faculty of calculating, speculating, and machinating (closely echoing Heidegger's Entwurf) was crucially, in Defoe's account, birthed in the planting of foreign colonies:

But here begins the forming of public joint-stocks, which, together, with the East India, African, and Hudson Bay Companies, before established, begot a new trade, which we call by a new name, stockjobbing, which was at first only the simple occasional transferring of interest and shares from one to another . . . but by the industry of the Exchange brokers, who got the business into their hands, it became a trade, and one, perhaps, managed with the greatest intrigue, artifice, and trick ever anything that appeared with a face of honesty could be handled with. ${ }^{75}$ 
Defoe was not alone with his sneering observations. The seemingly wellintentioned gentleman who comes up with the infamous scheme to alleviate and simultaneously capitalize on the famine in Ireland by turning children into livestock in Jonathan Swift's grim parody from 1729 is precisely a "projector." 76 Swift's projector is someone who "computes," on no matter what, and whose computations turn literally anything, even (or perhaps first and foremost) human life, into a commodity:

The number of souls in this kingdom being usually reckoned one million and a half, these I calculate there may about two hundred thousand couple, whose wives are breeders; from which number I subtract thirty thousand couple, who are able to maintain their own children (although I apprehend there cannot be so many under the present distresses of the kingdom) but this being granted, there will remain a hundred and seventy thousand breeders. ${ }^{77}$

And so on. Swift's projector subjects the fates of individuals and populations to the calculation of prices and proportions, statistical scrutiny, and the prediction of economic gain. His profile thereby caricatures the physiognomy of seventeenth- and eighteenth-century mercantilists, among them Sir William Petty, a fellow of the Royal Society known for developing the science of "political arithmetic," an early version of what is nowadays called "social statistics."78 Petty's ideal was a governmental rationality that worked "in Terms of Number, Weight, or Measure" and considered different segments of populations and resources in terms of their financial worth above anything else. ${ }^{79}$ The riches of the state boiled down to its people, who were regarded in the first instance as economic beings who could be divided into categories based on the quantity and character of their production. ${ }^{80} \mathrm{In}$ the extreme, individuals became mere transferable forms of money:

The value of people, Men, Women and Children in England, some have computed to be $£ 70$ per Head, one with another. But if you value the people who have been destroyed in Ireland, as Slaves and Negroes are usually rated, viz. at about $£ 15$ one with another; Men being sold for $£ 25$ and Children $£ 5$ each; the value of the people lost will be about $£ 10,355,000$. $^{81}$

The projector at the start of the eighteenth century saw the world through numerical tabulae - mortality tables, birth rates, casualty figures, quantities of livestock, numbers of buildings—indeed, through records and grids "on which lines, numbers, and changing characters are inscribed," as Gilles Deleuze observes about the emerging patterns of perception during the period. ${ }^{82}$ These grids gave expression to the world in terms of constants and 
regularities, even regularities of irregularities such as accidents. The world was no longer a steady dwelling of divine harmonies; instead, it was made of uncertainties and risks and, alternatively, of probabilities and unheard-of opportunities for future gain. Risk, the future's openness-the very idea of the possible-presented itself as something that one could capitalize on. Financial services such as insurance were developed for precisely this purpose. What insurance did was to detach the value of objects from actual marketplace exchange and attach it to imaginary transactions. ${ }^{83}$ The value of a cargo — say, a shipment of slaves—was calculated by imagining a typical exchange that might (or, rather, will) have taken place, based on a purely speculative market. Value was no longer tied to literal exchange or even the life of real bodies and things; it was freed to float open-ended as an imaginary valuation and promise of future payment.

Objects and relations thus became not only gridded and crunched by numbers but referenced in relation to visualizations of what might yet be realized and to speculative scenarios that were located, uneasily for many of their contemporaries, on the ontological no-man's-land between what is merely illusory and manipulated and what is not. ${ }^{84}$ The mutations that the concept of property underwent during the financial revolution crystallize this. As J.G.A. Pocock points out, by the late seventeenth century, “property - the material foundation of both personality and government-has ceased to be real and has become not merely mobile but imaginary." ${ }^{5}$ Similar to what insurance did to value, systems of credit such as government shares, bank notes, and individual traders' bills of exchange dislodged property from land or goods and indexed it to promises about the future. "What one owned was promises," Pocock writes, "and not merely the functioning but the intelligibility of society depended upon the success of a program of reification." 86 Not only economic but significant sociopsychological, even anthropological, stakes were at play in this transformation. ${ }^{87}$ The development of finance capitalism accompanied the rise of a new social person who, disinhibited from land and the family tree, was free to attach him- or herself to expectations, calculations, and imaginary gains. This was a subject motivated by self-interest and driven by desires, passions, and whims; a "projector," who, absorbed in his schemes, did "not even live in the present, except as constituted by his fantasies concerning a future." ${ }^{88}$ And this person participated in a society that itself resembled a joint-stock company: an aggregate of egoistic individuals acting on the marketplace, pulled now by this, now by that promise of profit. ${ }^{89}$

This new mindset and order of the world would not be possible without medial supports. "The open and unfinished emerges with techniques that enable us to write the merely possible and operationalize the nonrealized,"

\footnotetext{
De wind koopers met wind betaald, of de laaste zal blyven hangen (Wind buyers paid in wind, or those who are last will remain hanging on). Detail of a satirical illustration showing stockbrokers and investors at the courtyard of the Old Exchange in Amsterdam. From Het groote tafereel der dwaasheid (Amsterdam, ca. 1720). (c) Trustees of the British Museum.
} 
Bernhard Siegert notes. ${ }^{90}$ Written financial promises such as bank notes, bills of exchange, bonds, stocks, and shares fall within techniques of this ilk-techniques that operationalized a speculative ontology. The medium of paper became a bearer of value in terms of future expectations. Several of the satirical illustrations included in the Dutch folio of engravings titled Het groote tafereel der dwaasheid ("The great picture of folly"), compiled in the early 1720s, demonstrated the importance of various kinds of pieces of paper, filled with handwriting, to the practice of "stock-jobbing," and, in general terms, to the circulation of the promissory notes, bonds, and deposit receipts that the credit economy consists of.

Projected images should be considered alongside these early media of financialization. Operationalization of the unrealized and the imaginary was the key meaning of projection in late-seventeenth-century England, in the sense of both speculation and the creation of virtual views. Projection meant rendering the world as temporally unfinished and open-just as the drawings produced by means of Hooke's picture box were meant to be mere outlines and abstractions (or should we instead talk of transactions?) of things and beings yet to be "completed." Projection provided an ontological format for mediating the possible, for separating (or enclosing) the subject from (or within) her or his surroundings and thereby transforming what one sees in front of one's eyes from objects into projects. What the screen of the camera obscura operationalized were "shadows of expectation," as Defoe calls the imaginary projections of stockjobbers' and investors' entities of the future. ${ }^{91}$

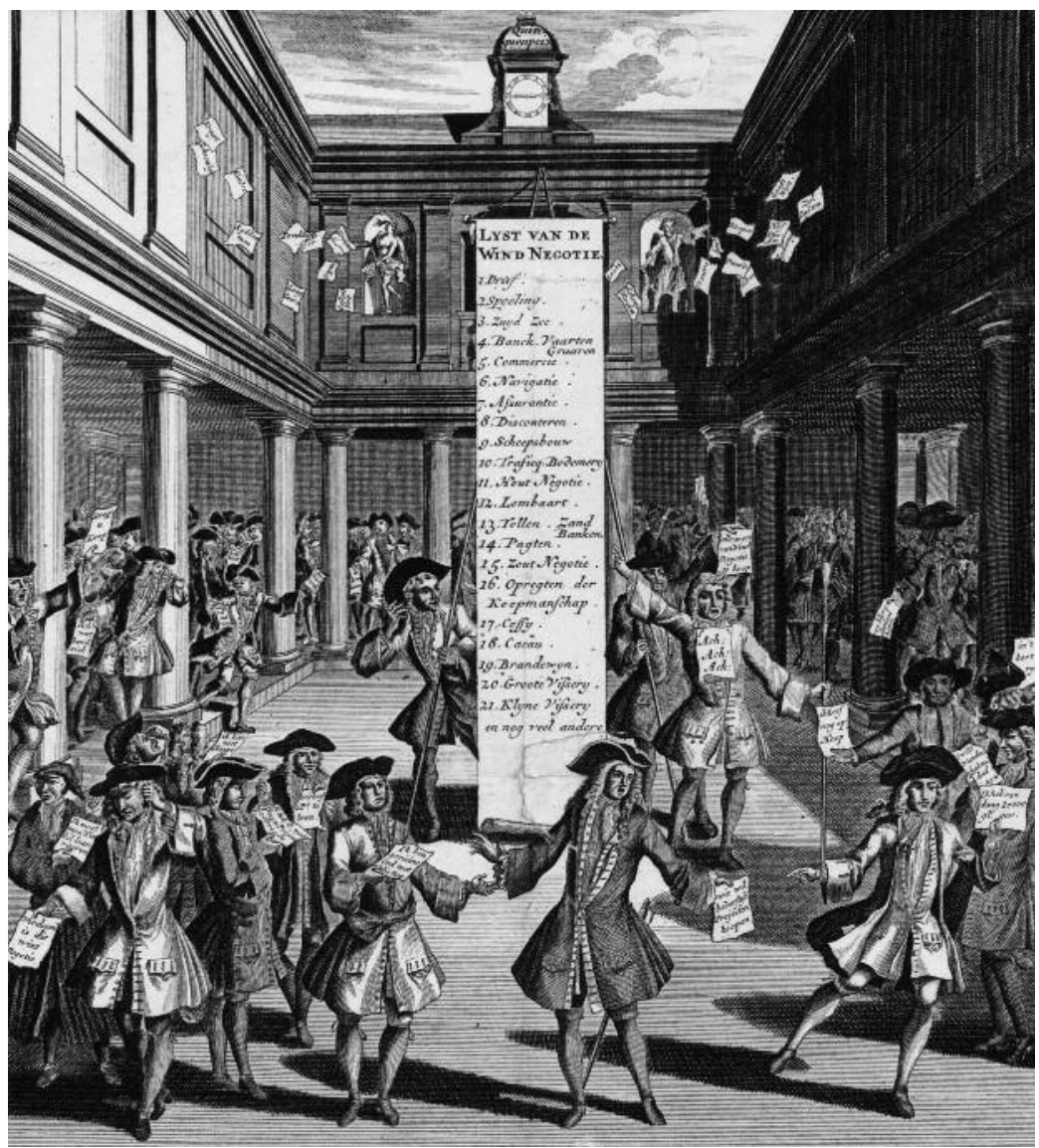


The picture box's projected images subscribed to the financial revolution's "program of reification," whereby the real and the knowable were annexed to the imagined and the anticipated. One of the functions of the box was to discipline flights of fancy, to offer a remedy for the perils of the imagination. But this was the device's operational goal only in relation to description and epistemology. Ontologically, the picture box virtualized the world, driven by the promise of future possessions - of lands and goods that could be harnessed, of natives that could be turned into objects of commerce-as well as by expectations of what one's investments in the shares of transatlantic trading could return. What were ultimately projected on the device's screen were not actual states of affairs or the artificial reality of entertainment but the "deferred reality" (to use Fernand Braudel's phrase) of credit and, by extension, of colonial expansion more generally. ${ }^{92}$

\section{"Disgusting Bubbles"}

“Speculation,” Samuel Johnson's 1756 dictionary of English tells us, meant, among other things, a "mental scheme not reduced to practice." 93 Optical projections, as Hooke's picture box illustrates, provided the key format for such mental operations at the turn of the eighteenth century. The projections of the camera obscura that Hooke designed, when considered within their political-economic circumstances, were to unmoor the observer's gaze and gestures from the here-and-now and turn them toward the future, thereby overcasting the real with the shadows of whatever expectations one might at a given time have come up with. This is what Hooke crystallized, without fully realizing it, with his little design: how optical projection came to tally with knowing, knowing with possession, and possession with speculation. Furthermore, during the early days of experimental science, finance capitalism, and colonialism in Europe, projection became a key cultural form through which economic, epistemic, and social activities were understood. Projection stood for liberation-liberation of the possessive individual's imagination from the material confines of the present-but at once the individual's subjection into an emerging global apparatus of debt.

Many of the developments taking place in England were also being spearheaded in the Netherlands. The Dutch, like the English, laid the foundations of empirical and experimental knowledge on visual description, and they were particularly driven by what Svetlana Alpers dubs the "mapping impulse" to project and survey the world as its own image. ${ }^{94}$ With their visualizations, the Dutch (contrary to Alpers's claims), were by no means lacking their fellow Englishmen's ambition for colonial expansion and commercial conquests, and they certainly had embraced, as the following tale intimates, the art of projection as one of possession and speculation. ${ }^{95}$ 
A dwarfish figure named "Night-Wind Singer of Shares" tramps along with his walking stick, mouth open, about to shout something. On his back he carries a magic lantern. ${ }^{96}$ This is one of the satirical illustrations the reader encounters in Het groote tafereel der dwaasheid, the folio of engravings made sometime after a major financial crisis shook Europe in 1720. The crisis started in London with the burst of the "South Sea Bubble," a scheme made to settle the massive debts the English government had run up by 1719 after three decades of waging war. The creditors who held almost one-third of the debt in government bonds were to exchange their long-term annuities for shares in the newly founded South Sea Company, with the incentive of making better returns. ${ }^{97}$ The South Sea Company had risen to prominence after being granted a monopoly contract from the Spanish government to supply South America with slaves (even if the trade itself, what little there was, was not profitable). For the scheme to work, the company's share price had to be driven up. With false promises spread about the profitability of potential pursuits overseas, and amid a general frenzy of speculation propelled by fantasies of fortunes made by "stock-jobbing," the value of the share rose from $£ 170$ per share in January 1720 to a peak of $£ 950$ in March, only to plummet back to $£ 170$ three months later. The fall was precipitated by new government measures against financial speculation and by declining confidence among English and foreign investors. The consequences vastly exceeded the fortunes lost, or made, in investing in South Sea Company shares alone. A general crisis in the stock market and a fall of the price of securities spread from London to Paris, where similar projects of restructuring government debt (plotted by the Scotsman John Law) through

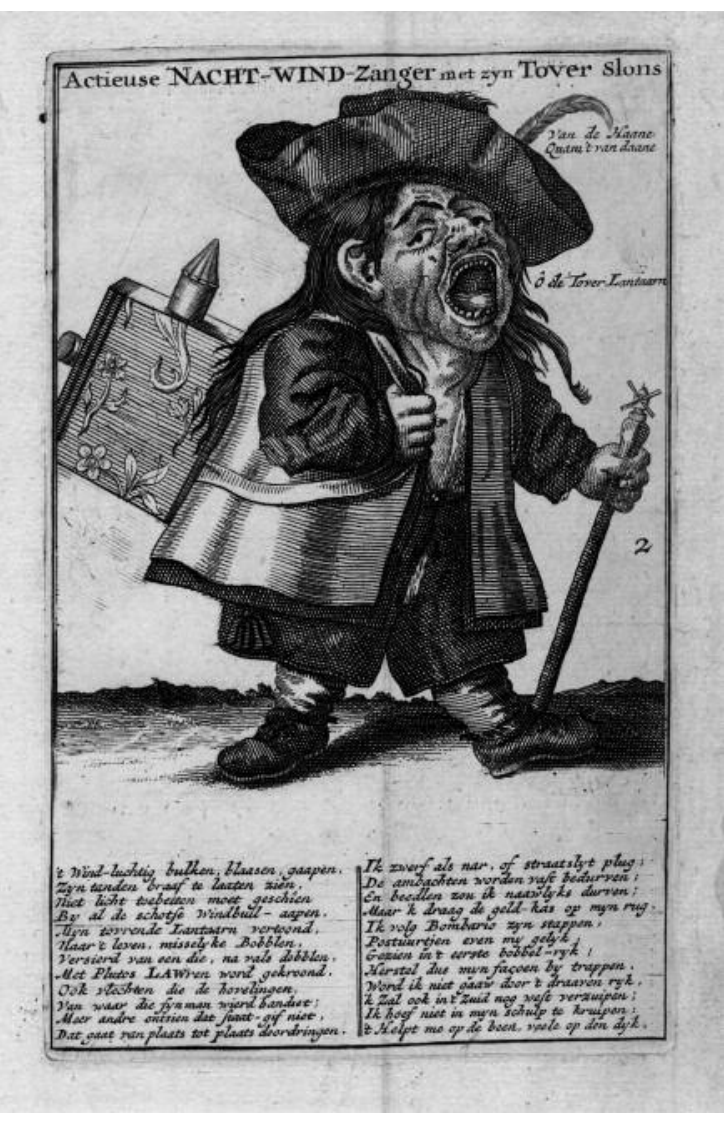
speculation with the promises of colonial exploits collapsed simultaneously, eventually spreading from Paris to Amsterdam.

The Singer of Shares roamed the streets of Amsterdam selling stock to credulous investors before the bubble's burst, trading when others had already gone to sleep. Het groote tafereel uses the expression "windtrade" (windhandel) to account for the transitory, immaterial, uncontrollable, and whimsical nature of speculation. But of main interest here is the technological metaphor the engraving puts forward: the magic lantern on the scheming man's back. A relatively new media technology during the period, the magic lantern was basically an 
offspring of the camera obscura, which turned the dark room's operating principle inside out: shadow pictures could be projected outside the apparatus through a transparent slide by means of a candle (or any light source) and a system of lenses and mirrors. At sunset, one can imagine, the dwarfish "projector" took out his technological counterpart and cast virtual images on a canvas to the surprise and wonder of his audience, images that appeared and disappeared, multiplied and transformed themselves without apparent cause. ${ }^{98}$ These projections were essentially unfixed from any material referent, not determined by their environment-a considerable development over the camera obscura. Therefore, they provided an apt analogy for the imaginary objects of speculation freed from the constraints of real bodies and things. The magic lantern projected "disgusting bubbles" (misselijke Bobbelen), as the inscription below the engraving suggests. The shadows of expectation animating finance were just like the shadows cast by the device. That is, both credit economy and the magic lantern were operationally premised on the projection of virtual realities onto things and relations.

Thus, the dwarfish Singer of Shares, carrying his neatly decorated apparatus on his back, corroborates projection's rise to a prominent cultural status by the early eighteenth century. Something in the form of the projected image crystallized, both intuitively and conceptually, what the new economic realities meant. Should we therefore conclude that, at the start of the eighteenth century, projection became a "symbolic form" that "laid the foundation for a new conception of what a picture is"-and hence of what the world could be turned into ${ }^{99}$ Ernst Cassirer defines the symbolic form as creating "the only possible and adequate mediation and medium through which any spiritual being becomes comprehensible and intelligible.”100 Symbolic forms, that is, make mental operations such as speculative scenarios intellectually possible.

Could we not argue that starting in the late seventeenth century the projected image allowed being itself to be turned into an object of speculation? That the projected image became a symbolic form crystallizing the culture of the financial revolution? That the projected images have been the guiding mental operations of the type of capitalism whose effects we today experience deep within our skins? Today, optical projections have been replaced by mathematical formulas for mastering the future; computing machines and algorithms have substituted for dark rooms and magic lanterns. ${ }^{101}$ The current credit economy's media infrastructure has an apparently different past from the one discussed above. Yet, insofar as today's finance capitalism still rests on a psychic domain that stipulates the nonexisting (or potentially existing) as its driving force-insofar as it still depends on speculative projections of all sorts as its mental optics-its media history, we may tentatively conclude, started in the dark room. 
An earlier version of this essay has appeared in German as "Verkörperter Bildkasten: Projektive Bildschirme und visuelle Imperien um 1700,” in Image Guidance: Bedingungen bildgeführter Operation, vol. 12 of Bildwelten des Wissens: Kunsthistorisches Jahrbuch für Bildkritik, ed. Kathrin Friedrich, Moritz Queisner, and Anna Roethe (Berlin: De Gruyter, 2016), 62-72.

1. Robert Hooke, “An Instrument of Use to Take the Draught, or Picture of Any Thing," in Philosophical Experiments and Observations of the Late Eminent Dr. Robert Hooke, ed. William Derham (London, 1726), 292-96.

2. See Hans Belting, Florence and Baghdad: Renaissance Art and Arab Science, trans. Deborah Lucas Schneider (Cambridge, MA: Harvard University Press, 2011), 90-97.

3. See, for example, Philip Steadman, Vermeer's Camera: Uncovering the Truth behind the Masterpieces (Oxford, UK: Oxford University Press, 2001).

4. Robert Boyle, Tracts about the Cosmical Qualities of Things, Cosmical Suspicions, the Temperature of the Subterraneal Regions, the Temperature of the Submarine Regions, the Bottom of the Sea (Oxford, 1671), 18-19 (ch. 6).

5. Hooke, “An Instrument of Use," 292-93.

6. Hooke, “An Instrument of Use,” 295.

7. Hooke, "An Instrument of Use," 294.

8. Svetlana Alpers, The Art of Describing: Dutch Art in the Seventeenth Century (Chicago: University of Chicago Press, 1983), 135.

9. According to Matthew Hunter, the print is "reconcilable with no surviving plans" by Hooke. Matthew C. Hunter, “'Mr. Hooke’s Reflecting Box’: Modeling the Projected Image in the Early Royal Society,” Huntington Library Quarterly 78, no. 2 (2015): 314.

10. Christoph Scheiner, Rosa Ursina sive Sol (Bracciani, 1626-1630), 106, quoted in Michael John Gorman, "Projecting Nature in Early-Modern Europe," in Inside the Camera Obscura-Optics and Art under the Spell of the Projected Image, ed. Wolfgang Lefèvre (Berlin: Max-Planck-Institut für Wissenschaftsgeschichte, 2007), 38; available online at https://www.mpiwg-berlin.mpg.de/Preprints/P333.PDF. On Hooke's picture box as an early head-mounted display system, see David Tomas, Beyond the Image Machine: A History of Visual Technologies (London: Continuum, 2004), 105-24.

11. Hooke, "An Instrument of Use," 293.

12. Robert Hooke, "A Contrivance to Make the Picture of Any Thing Appear on a Wall, Cub-Board, or within a Picture-Frame," Philosophical Transactions 3, no. 38 (1668): 741-43. On Hooke's experiment, see also Jill H. Casid, Scenes of Projection: Recasting the Enlightenment Subject (Minneapolis: University of Minnesota Press, 2015), 50-54.

13. Hooke, "A Contrivance," 742.

14. Hooke's ideas were not entirely novel here either. The Italian polymath Giambattista della Porta had already in his 1558 work Magiae naturalis (Natural magic), which was first translated and published in English in 1658, envisioned that the camera obscura could be used to stage "huntings, banquets, armies of enemies, plays, and all things else that one desireth.” Porta, like Hooke about 110 years later, was interested in the illusory powers of projection, in the creation of artificial realities by means of shadow optics. See Siegfried Zielinski, Deep Time of the Media: Toward an Archaeology of Hearing and Seeing by Technical Means, trans. Gloria Custance (Cambridge, MA: MIT Press, 2006), 86. 
15. See Daniel Carey, "Compiling Nature's History: Travellers and Travel Narratives in the Early Royal Society," Annals of Science 54, no. 3 (1997): 269-92; John Gascoigne, "The Royal Society, Natural History and the Peoples of the 'New World(s),' 1660-1800," British Journal for the History of Science 42, no. 4 (2009): 539-62; Sarah Irving, Natural Science and the Origins of British Empire (London: Pickering and Chatto, 2008), 3; and Barbara J. Shapiro, A Culture of Fact: England, 1550-1720 (Ithaca: Cornell University Press, 2000), 72-76.

16. As Matthew Hunter points out, "among the networks of Royal Society informants moving through Turkey, Egypt, South Asia, the American colonies, and numerous points in between, . . . few correspondents made images themselves or actually knew how to draw." Matthew C. Hunter, Wicked Intelligence: Visual Art and the Science of Experiment in Restoration London (Chicago: University of Chicago Press, 2013), 18.

17. See Hunter, Wicked Intelligence, 125-58.

18. Robert Hooke, The Posthumous Works of Dr. Robert Hooke, ed. Richard Waller (London, 1705), 338.

19. This is the key argument developed by Irving in Natural Science and the Origins of British Empire (see, e.g., 22).

20. Francis Bacon, New Atlantis, in Francis Bacon: The Major Works, ed. B. Vickers (Oxford, UK: Oxford University Press, 2002), 480; quoted in Irving, 2. On Hooke and Bacon, see Peter Harrison, The Fall of Man and the Foundations of Science (Cambridge, UK: Cambridge University Press, 2007), 199-200.

21. Henry Oldenburg to René François Sluse, 23 October 1667, quoted in Irving, 94.

22. See Anna Winterbottom, Hybrid Knowledge in the Early East India Company World (Basingstoke: Palgrave Macmillan, 2016), 13.

23. Irving, 1.

24. On the East India Company, see Nick Robins, The Corporation That Changed the World: How the East India Company Shaped the Modern Multinational (London: Pluto Press, 2006).

25. Robert Boyle, Experimenta et Observationes Physicae, in The Works of the Honourable Robert Boyle (London, 1772), 5:575; and Boyle, The Works of the Honourable Robert Boyle, 1:cviii.

26. Boyle, A Disquisition about the Final Causes of Natural Things, in The Works of the Honourable Robert Boyle, 5:411. See also Irving, 73.

27. Gen. 1:26 (1611 King James version).

28. Robert Hooke, lecture on 18 December 1697, quoted in Michael Hunter, Boyle Studies: Aspects of the Life and Thought of Robert Boyle (1627-91) (London: Routledge, 2016), 211.

29. Carey, 271-73.

30. Robert Boyle, "General Heads for a Natural History of a Countrey, Great or Small," Philosophical Transactions 1 (1665-1666): 186-89.

31. On the production of Knox's Relation, see Anna Winterbottom, "Producing and Using the Historical Relation of Ceylon: Robert Knox, the East India Company and the Royal Society," British Journal for the History of Science 42, no. 4 (2009): 515-38, esp. 521-27.

32. Robert Hooke, preface to An Historical Relation of the Island of Ceylon, by Robert Knox (London, 1681), A2r. The first volume of the Royal Society's publication Philosophical Transactions included a list of directions for "Sea-men going into the East \& West-Indies, the better to capacitate them for making such observations abroad, as may be pertinent and suitable for the purpose; of which the said Sea-men should be desired to keep an exact Diary, 
delivering at their return a fair Copy thereof to Lord High Admiral of England, his Royal Highness the Duke of York, and another to Trinity-house to be perused by the R. Society." "Directions for Sea-Men, Bound for Far Voyages," Philosophical Transactions 1 (1665): 141.

33. Hooke, "An Instrument of Use," 293-94.

34. See Hunter, Wicked Intelligence, 120.

35. On the illustrations in Knox's Relation, see Winterbottom, "Producing and Using the Historical Relation of Ceylon," 522. Ogilby's America was a translation of De nieuwe en onbekende weereld (1671), written by Arnoldus Montanus, who never actually visited the New World. Hooke had a copy of America in his library, and it is included in the list of books with misleading illustrations that Hooke mentions: "Such are all the Pictures in the Books of Theodore de Brie, concerning the East and West-Indies: Such are also the greatest Part of the Pictures in Sir Thomas Herbert's Travels; and those of Mr. Ogylby's Asia, Africa, and America; which are Copies of the Dutch Originals, and are, originally, nothing but Mr. Engraver's fancy." Hooke, "An Instrument of Use," 293-94.

36. Hooke, "An Instrument of Use," 294.

37. Robert Hooke, diary entry from 22 September 1683, in British Library, MS Sloane 1039, f. 156. On the diary entry, see Winterbottom, Hybrid Knowledge, 155; and Winterbottom, "Producing and Using the Historical Relation of Ceylon," 520.

38. See Thomas Birch, The History of the Royal Society of London, vol. 2 (London, 1756), 436-42. On Hooke's involvement in different camera obscura designs throughout his career, see Hunter, “'Mr. Hooke's Reflecting Box,” 308-15.

39. Birch, 442.

40. Hooke, "An Instrument of Use," 294.

41. See Hooke, The Posthumous Works, 126-27.

42. Hunter, Wicked Intelligence, 43-49.

43. Robert Hooke, Micrographia: Or Some Physiological Descriptions of Minute Bodies Made by Magnifying Glasses with Observations and Inquiries Thereupon (London, 1665), A2r, A2v.

44. On the camera obscura as a drawing aid able to represent and reproduce things and beings in their "natural disposition," see also the short treatise by Hooke's contemporary, Dutch natural philosopher Willem Jacob 's Gravesande, "Usage de la chambre obscure pour le dessein," in Essai de perspective (The Hague: Veuve d'Abraham Troyel, 1711).

45. Hooke, "A Contrivance," 742.

46. Gorman, "Projecting Nature in Early-Modern Europe," 36.

47. See Carsten Writh, "The Camera Obscura as a Model for a New Concept of Mimesis in Seventeenth-Century Painting," in Inside the Camera Obscura, 149-93, esp. 152.

48. Sean Silver, The Mind Is a Collection: Case Studies in Eighteenth-Century Thought (Philadelphia: University of Pennsylvania Press, 2015), 65. Silver (56-66) discusses how the camera obscura became a model for the mind in early Enlightenment, particularly in Hooke, John Locke and Thomas Willis. See also Jonathan Crary's analysis of the camera obscura's "interiorized observer" in Techniques of the Observer: On Vision and Modernity in the Nineteenth Century (Cambridge, MA: MIT Press, 1990), 25-66.

49. See Bernhard Siegert, Cultural Techniques: Grids, Filters, Doors, and Other Articulations of the Real, trans. Geoffrey Winthrop-Young (New York: Fordham University Press, 2015), $129-46$.

50. Christian Jacob, The Sovereign Map: Theoretical Approaches in Cartography through- 
out History, trans. Tom Conley, ed. Edward H. Dahl (Chicago: University of Chicago Press, 2005), 325. See also Tim Ingold's critique of colonial imaginary in Being Alive: Essays on Movement, Knowledge, and Description (London: Routledge, 2011), 168.

51. J.B. Harley, "Maps, Knowledge and Power," in The Iconography of Landscape: Essays on the Symbolic Representation, Design and Use of Past Environments, ed. Denis Cosgrove and Stephen Daniels (Cambridge, UK: Cambridge University Press, 1988), 277-312, esp. 285.

52. "A tangent projection from a projection on a sphere, but only great circles which passt the centre with the straight lines. Others will be conicall curves," Hooke noted in his diary in September 1683, his mind having been preoccupied by cartographic projection. Hooke, diary entry from 22 September 1683, in British Library, MS Sloane 1039, f. 156. On Hooke's camera obscura models as prototypes for modern surveying techniques, see M.A.R. Cooper, “Robert Hooke (1635-1703): Proto-Photogrammetrist," Photogrammetric Record 15 (1996): 403-17, esp. 409-11. On Hooke's involvement in various cartographic projects, see E.G.R. Taylor, "Robert Hooke and the Cartographic Projects of the Late Seventeenth Century (1666-1696)," Geographical Journal 90, no. 6 (1937): 529-40.

53. "'I see, I draw, I conquer' is the etching's implied caption," Kaja Silverman notes about the illustration of the picture box. Kaja Silverman, The Miracle of Analogy, or, The History of Photography, Part 1 (Stanford, CA: Stanford University Press, 2015), 70.

54. See Winterbottom, Hybrid Knowledge. Winterbottom demonstrates that the production of knowledge of the natural world was imperative to European expansion and the beginnings of colonialism. See also Kapil Raj, Relocating Modern Science: Circulation and the Construction of Knowledge in South Asia and Europe, 1650-1900 (Basingstoke: Palgrave Macmillan, 2007), 15-18.

55. Minutes of the Union Commissioners 1702-3, 16 December 1702, in British Museum, MS Harl. 4959, f. 21, quoted in P.G.M. Dickson, The Financial Revolution in England: A Study in the Development of Public Credit 1688-1756 (London: Macmillan, 1967), 8.

56. Locke, An Essay Concerning Human Understanding, bk. 4, ch. 12, §10.

57. Irving, 117-19.

58. See Irving, 113.

59. John Locke, Two Treatises of Government, in vol. 4 of The Works of John Locke, in Nine Volumes, 12th ed. (London, 1824), bk. 2, ch. 5, §32; emphasis in original.

60. Locke, Two Treatises of Government, bk. 2, chap. 5, §27.

61. The term possessive individualism was first coined by C.B. Macpherson in his analysis of seventeenth-century English political thought. See C.B. Macpherson, The Political Theory of Possessive Individualism: Hobbes to Locke (Oxford, UK: Oxford University Press, 1992).

62. As Sean Silver argues about the picture box, "seeking and taking is after all the very purpose of Hooke's object." Silver, 64.

63. Gen. 1:28 (1611 King James version). On outlining (by means of Hooke’s picture box and other drawing devices) in terms of "spatial enclosure," see Hunter, Wicked Intelligence, $45-49$.

64. Hugo Grotius, The Free Sea, trans. Richard Haklyut, ed. David Armitage (Indianapolis: Liberty Fund, 2004), 13.

65. Martin Heidegger, "The Age of the World Picture," in The Question Concerning Technology and Other Essays, trans. William Lovitt (New York: Garland Publishing, 1977), 
115-54, esp. 118-26.

66. Heidegger, "The Age of the World Picture,” 118.

67. On the special effects of the camera obscura, see Steadman, Vermeer's Camera, 161-62.

68. Malachy Postlethwayt, The Universal Dictionary of Trade and Commerce, vol. 1, 4th ed. (London, 1774), s.v. "bubble." The jingle is actually a slight modification of two lines from Samuel Butler's poem Hudibras, from the 1660s-1670s: "For what is worth in anything, / But so much money as 'twill bring?” Butler, Hudibras, vol. 1 (London: Henry G. Bohn, 1859), pt. 2, canto 1, lines 465-66 (p. 153).

69. Daniel Defoe, “An Essay upon Projects,” in The Earlier Life and Works of Daniel Defoe, ed. Henry Morley (London: George Routledge and Sons, 1889), 25. On the notions of "projector" and "projection” in Defoe, see Kimberley Latta, "'Wandring Ghosts of Trade Whymsies': Projects, Gender, Commerce, and Imagination in the Mind of Daniel Defoe,” in The Age of Projects, ed. Maximillian E. Novak (Toronto: University of Toronto Press, 2008), 141-65.

70. Samuel Johnson, A Dictionary of English Language, vol. 2 (London, 1756), s.v. "projector."

71. Johnson, A Dictionary of English Language, vol. 2, s.v. "to project."

72. Defoe, “An Essay upon Projects,” 31-32.

73. See Dickson, 6-10; and Ian Baucom, Specters of the Atlantic: Finance Capital, Slavery, and the Philosophy of History (Durham, NC: Duke University Press, 2005), 38. On the political and economic background for the financial revolution, see Steven C.A. Pincus, "A Revolution in Political Economy?” in The Age of Projects, 116-40.

74. Defoe, "An Essay upon Projects," 33.

75. Defoe, "An Essay upon Projects,” 42-43.

76. Jonathan Swift, "A Modest Proposal for Preventing the Children of Poor People in Ireland from Being a Burden to Their Parents or Country, and for Making Them Beneficial to the Publick," in The Works of the Rev. Jonathan Swift, D.D., vol. 9 (London, 1801), 287-99.

77. Swift, "A Modest Proposal," 289.

78. See George Wittkowsky, "Swift's Modest Proposal: The Biography of an Early Georgian Pamphlet," Journal of the History of Ideas 4, no. 1 (1943): 75-104; and Charlotte Sussman, "The Colonial Afterlife of Political Arithmetic: Swift, Demography, and Mobile Populations," Cultural Critique 56 (Winter 2004): 96-126. Petty’s political arithmetic contributed to the beginnings of political economic thinking and new kinds of governmental rationalities and practices that Michel Foucault considered (reconsidering an old concept) in terms of "biopolitics." The new "subject-object” of biopolitics was, precisely, the population: "For example: knowledge of the population, the measure of its quantity, mortality, natality; reckoning of the different categories of individuals in a state and of their wealth; assessment of the potential wealth available to the state, mines and forests, etcetera; assessment of the wealth in circulation, of the balance of trade, and measure of the effects of taxes and duties, all this data, and more besides, now constitute the essential content of the sovereign's knowledge.” Michel Foucault, Security, Territory, Population: Lectures at the Collège de France, 1977-1978, ed. Michel Senellart, trans. Graham Burchell (Basingstoke: Palgrave Macmillan, 2009), 274.

79. William Petty, Political Arithmetick, in The Economic Writings of Sir William Petty, vol. 1, ed. Charles Henry Hull (Cambridge, UK: University Press, 1899), 244. 
80. Sussman, 103.

81. William Petty, The Political Anatomy of Ireland, in The Economic Writings of Sir William Petty, vol. 1, 152. On individuals as forms of money in the context of the slave trade, see Baucom, 60-61.

82. Gilles Deleuze, The Fold: Leibniz and the Baroque, trans. Tom Conley (London: Athlone Press, 1993), 27.

83. See Baucom, 95-96.

84. See Joseph Vogl, The Specter of Capital, trans. Joachim Redner and Robert Savage (Stanford, CA: Stanford University Press, 2015), 36-42.

85. J.G.A. Pocock, Virtue, Commerce and History: Essays on Political Thought and History, Chiefly in the Eighteenth Century (Cambridge, UK: Cambridge University Press, 1985), 112.

86. Pocock, 113.

87. Joseph Vogl observes that the financial revolution was "nothing short of a moral and anthropological revolution.” Vogl, The Specter of Capital, 21.

88. Pocock, 112. On the new social person, see also Vogl, The Specter of Capital, 18-23.

89. In Locke's writings, for instance, the state became modeled based on a joint-stock venture in the appropriation of the colonies: "Perhaps the closest analogue of Locke's state is the joint-stock company of merchants trading to or planting in distant lands, whose charter gives them, or allows them to take, such jurisdiction over the natives or the transplanted labour force as the character of the trade requires." Macpherson, The Political Theory of Possessive Individualism, 252.

90. Siegert, 144.

91. Defoe, "An Essay upon Projects," 34.

92. "But if it is possible to say that everything is money, it is just as possible to claim that everything is, on the contrary, credit—promises, deferred reality," Braudel points out. Fernand Braudel, The Structures of Everyday Life: The Limits of the Possible, vol. 1 of Civilization and Capitalism: 15th-18th Century, trans. Siân Reynolds (London: William Collins Sons, 1981), 476.

93. Johnson, A Dictionary of English Language, vol. 2, s.v. "speculation."

94. Alpers, $72-168$.

95. Alpers asserts that the "dreams of surveillance and power as the fruit of man's knowledge of nature" that one could find in the pursuits of the Royal Society of London "were not taken up in the Netherlands." Alpers, 72. For contrasting interpretations, see, for example, Julie Berger Hochstrasser, Still Life and Trade in the Dutch Golden Age (New Haven: Yale University Press, 2007); Dániel Margócsy, Commercial Visions: Science, Trade, and Visual Culture in the Dutch Golden Age (Chicago: University of Chicago Press, 2014); and Elizabeth A. Sutton, Capitalism and Cartography in the Dutch Golden Age (Chicago: University of Chicago Press, 2015).

96. The dwarfish showman from Het groote tafereel made his first appearance in the book Il Callotto resuscitato, oder, Neu eingerichtes Zwerchen Cabinet from circa 1715, a collection of caricatures of dwarfs in various roles and professions inspired by the French draftsman Jacques Callot's "Grotesque Dwarves." Il Callotto identifies the showman as "Nicolo Cantabella, Savoyardischer Würmschneider," a "beautiful singer" and a trickster (to translate the description freely) from Savoy. In the original illustration, he is shown carrying a neatly decorated peepshow box instead of a magic lantern on his back. The Savoyards were a group of itinerant showmen and women who roamed across Europe during the eighteenth 
century, displaying mechanical instruments, magic lanterns, peep shows, automata, and other technical wonders. During this time, they possessed "a virtual monopoly on the display of optical and mechanical curiosities." Deac Rossell, Laterna Magica/Magic Lantern, vol. 1 (Stuttgart: Füsslin Verlag, 2008), 107. On the Savoyards, see also Deirdre Loughridge, Haydn's Sunrise, Beethoven's Shadow: Audiovisual Culture and the Emergence of Musical Romanticism (Chicago: University of Chicago Press, 2016), 64-76.

97. For the following account, see Dickson, 90-156.

98. Stuart Clark, Vanities of the Eye: Vision in Early Modern European Culture (Oxford, UK: Oxford University Press, 2007), 101.

99. Belting, 17.

100. Ernst Cassirer, "The Concept of Symbolic Form in the Construction of the Human Sciences," in The Warburg Years (1919-1933): Essays on Language, Art, Myth, and Technology, trans. S.G. Lofts with A. Calcagno (New Haven: Yale University Press, 2013), 77. Erwin Panofsky analyzes perspective as a symbolic form that gave expression to the mathematization of being implemented in the theoretical space of the Renaissance. See Erwin Panofsky, Perspective as Symbolic Form, trans. Christopher S. Wood (New York: Zone Books, 1997).

101. See, for example, Joseph Vogl, "Taming Time: Media of Financialization," trans. Christopher Reid, Grey Room, no. 46 (Winter 2012): 76-83. 